\title{
The contribution of migratory mesopelagic fishes to neuston fish assemblages across the Atlantic, Indian and Pacific Oceans
}

\author{
M. Pilar Olivar ${ }^{\mathrm{A}, \mathrm{G}}$, J. Ignacio González-Gordillo ${ }^{\mathrm{B}}$, Jordi Salat ${ }^{\mathrm{A}}$, \\ Guillem Chust ${ }^{\mathrm{C}}$, Andrés Cózar ${ }^{\mathrm{B}}$, Santiago Hernández-León ${ }^{\mathrm{D}}$, \\ M. Luz Fernández de Puelles ${ }^{\mathrm{E}}$ and Xabier Irigoien ${ }^{\mathrm{F}}$ \\ A Institut de Ciències del Mar, Consejo Superior de Investigaciones Científicas, Passeig Marítim, \\ 37-49, E-08003 Barcelona, Spain. \\ ${ }^{B}$ Departamento de Biología, Facultad de Ciencias del Mar y Ambientales, Universidad de Cádiz, \\ Campus de Excelencia Internacional del Mar (CEI MAR), E-11510 Puerto Real, Spain. \\ ${ }^{C}$ AZTI-Tecnalia, Marine Research Division, Txatxarramendi ugartea z/g, E-48395 Sukarrieta, \\ Bizkaia, Spain. \\ D Instituto de Oceanografía y Cambio Global, Universidad de Las Palmas de Gran Canaria, \\ Campus Universitario de Tafira, E-35017 Las Palmas de Gran Canaria, Canary Islands, Spain. \\ ${ }^{E}$ M.L. Fernández de Puelles, Centro Oceanográfico de Baleares, Instituto Español de \\ Oceanografía, Muelle de Poniente s/n, E-07015 Palma de Mallorca, Spain.

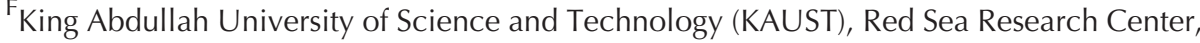 \\ Thuwal 23955-6900, Saudi Arabia. \\ ${ }^{\mathrm{G}}$ Corresponding author. Email: polivar@icm.csic.es
}

\begin{abstract}
Surface waters are an attractive foraging ground for small fish in the open ocean. This study aims to determine the importance of vertically migrating species in the neuston of oceanic waters across the Atlantic, Indian and Pacific Oceans and to ascertain the influence of environmental variables on their distribution patterns. Neustonic fish assemblages were primarily controlled by light. They were dominated by late-larvae and juveniles of Exocoetidae, Hemiramphidae and Scomberesocidae during the day. At night, the vertical migration of mesopelagic species changed the dominance pattern in favour of Myctophidae and Scomberesocidae. The neustonic families' distribution was primarily related to sea surface temperatures, whereas environmental variables at deeper layers were related to mesopelagic migrating families. Canonical correspondence analysis showed a low but statistically significant contribution of several environmental variables to myctophid species composition (10\%), with minimum oxygen concentrations ranking first in variance explanation followed by maximum fluorescence, sea surface temperature and 400-m temperature. Spatial autocorrelation also explained $17 \%$ of the variance, indicating the influence of other factors such as historical, demographic and dispersal constraints. The low number of myctophid species in the North Pacific Equatorial Countercurrent appears to be related to the low oxygen concentrations observed in this province.
\end{abstract}

Additional keywords: Ichthyoneuston, ichthyoplankton, micronekton, Myctophidae, oceanic realm, pelagic biogeography, vertical migration.

Received 2 December 2014, accepted 4 April 2015, published online 27 August 2015

\section{Introduction}

The neustonic realm comprises the uppermost centimetres of the water column. Buoyant resources accumulate in this ecotone, but its inhabitants are subject to high predation risks and environmental stresses due to intense solar radiation, wind stress and advection. Therefore, many species visit this habitat for foraging or breeding, but only a few fish species spend all their time there. The most commonly reported fish components of the oceanic neuston are species of beloniform families, e.g. Exocoetidae,
Hemiramphidae and Scomberesocidae (John 1977; Collette 2006). Many other fish species generally occupy the ocean surface for just a portion of the life cycle, i.e. larval (Katsuragawa and Matsuura 1990; Doyle et al. 1995) or juvenile stages (Tully and ÓCéidigh 1989), or for a part of the diel cycle, as is the case for the mesopelagic migrating fishes (Kawaguchi et al. 1972; Gartner et al. 1989; Watanabe et al. 2002).

Mesopelagic fishes constitute a highly diverse assemblage that inhabits the dark region of the oceans between 200 and 
$1000 \mathrm{~m}$ deep, but many of them feed in the rich near-surface layers at night (Gartner et al. 1997). This fish community dominates the world's fish biomass (Gjøsaeter and Kawaguchi 1980; Fock and Ehrich 2010; Irigoien et al. 2014) and is a common component in the diet of marine birds, mammals and large pelagic fishes but also serves as the staple food for demersal, benthopelagic and larger meso- and bathypelagic fishes (Cherel et al. 1993; Valls et al. 2014). The most abundant and common mesopelagic fishes are lanternfishes (Myctophidae), bristlemouths (Gonostomatidae) and hatchetfishes (Sternoptychidae). Most species of the family Myctophidae perform diel vertical migrations, but just a few species of Gonostomatidae are reported to reach the epipelagic zone (Badcock and Merret 1976; Watanabe et al. 1999; Flynn and Williams 2012; Olivar et al. 2012). The extent of vertical migrations also differs among species and developmental stages, with some myctophids characterised as nyctoepipelagic because they can reach the neustonic layer (Kawaguchi and Aioi 1972; Kawaguchi et al. 1972; Hulley 1981). As a result of this vertical migration pattern, myctophids play an important role in the transfer of matter and energy from the upper layers, where they feed, to the deep bottom environments, where they excrete, defecate, and can be preyed upon (Longhurst and Harrison 1989; Davison et al. 2013).

It is accepted that daily vertical migrations have a stronger influence on horizontal dispersal than long-term horizontal migrations for the micronekton (van der Spoel 1994). In the open ocean, environmental horizontal gradients are far weaker than vertical gradients, and the distributional patterns of oceanic species are often closely linked to the heterogeneity of the water column (Angel 1997). Horizontal distributions depend on the vertical location of the organisms and the differential influence of currents at different water layers. Most likely, it is for this reason that zoogeography appears more dependent on water mass configuration than on productivity.

Faunal centers in the world ocean are situated in water masses from which taxa spread over larger distances (and are not geographically fixed as on land) (Briggs and Bowen 2012), being distributions of organisms largely related to the distribution of water masses to which species have adapted their life history (Iles and Sinclair 1982; Sinclair 1988). The current geographic distributions of species are a combination of the mobility of populations (migration, transport), the selective pressure and the time during which the taxon has existed (van der Spoel and Heyman 1983). Regionalisation of the ocean is generally based on climatological, oceanographic or ecological aspects, from major subdivisions in global climatic regions to more comprehensive biogeographic provinces (Longhurst 1998). Therefore, we may hypothesise a certain correlation between fish species distributions and the common biogeographic classifications of the global ocean.

In the present study, we aim to determine the relative contribution of surface migrating myctophids to the overall neustonic fish assemblage in the oceanic waters of the three main oceans, Atlantic, Indian and Pacific, and to identify the main environmental factors shaping the species' distributions. We will also test whether the cross-ocean myctophid taxa are related to the Longhurst Biogeographical Provinces or show more extensive patterns.

\section{Materials and methods}

Samples were collected from December 2010 to July 2011 during the transoceanic Malaspina 2010, Spanish Circumnavigation Expedition across the Atlantic, Indian and Pacific Oceans. The survey was thus conducted starting in winter at the northern hemisphere in the Atlantic Ocean, going to the tropical areas. Then, the southern hemisphere was sampled from summer to autumn in the Atlantic-Indian-Pacific oceans. From western Pacific, the survey continued to the tropical zone and then to the Northern Pacific during early spring. Finally the north Atlantic ocean was crossed again at the end of spring and early summer. The samples here studied were collected from the neustonic layer with a neuston net with a mouth aperture of $1 \times 0.5 \mathrm{~m}$ and mesh size of $0.2 \mathrm{~mm}$. The ship speed was $2-3 \mathrm{kn}\left(\sim 1-1.5 \mathrm{~m} \mathrm{~s}^{-1}\right)$, and the net was hauled from 10 to $15 \mathrm{~min}$. Generally, every station was sampled both day and night. A total of 256 samples obtained at 147 stations were analysed for the present study (Fig. 1). Environmental data were obtained throughout the water column with CTD casts that extended from the surface down to $4000 \mathrm{~m}$.

The largest organisms, including adult fishes, were sorted on board and preserved in 5\% buffered formalin. The rest of the sample was also preserved in formalin and kept in the dark before sorting in the laboratory. Larvae and juveniles were identified according to general guides to the ichthyoplankton of different regions of the world (Olivar and Fortuño 1991; Moser 1996; Richards 2006; Fahay 2007). Adult myctophids were identified based on Bekker (1983), Hulley (1981, 1986a), Paxton et al. (1995) and J. R. Paxton and A. Williams (unpubl. data). Fish species abundance was standardised to the number of individuals per $1000 \mathrm{~m}^{2}$ using counts obtained from a flowmeter placed in the mouth of the net.

To test the relationship between neustonic fish species distribution and abundance and the environmental variables, a canonical correspondence analysis (CCA) was performed on the matrices of fish abundance (log-transformed) and matrices of environmental parameters. An initial CCA, including the different families occurring in both day and night samples, was performed. The taxa that appeared at less than two stations or whose abundance was less than $0.1 \%$ were excluded to avoid rare species having a disproportionate effect on the analyses. A second CCA was performed at the species level for myctophids. All the ordinations were performed using CANOCO version 4.5 (Ter Braak and Smilauer 2002). A matrix of environmental data was built using sea surface temperature (SST), salinity (SSS), fluorescence (SF), oxygen (SO), maximum fluorescence (Max. F), minimum oxygen (Min. $\mathrm{O}_{2}$ ), temperature at 200 and $400 \mathrm{~m}$ (T200, T400) and salinity at 200 and $400 \mathrm{~m}$ (S200, S400). Max. F is the highest fluorescence value in each CTD cast. Min. $\mathrm{O}_{2}$ values were the lowest oxygen concentrations found in the upper $500 \mathrm{~m}$. Owing to the marked differences among stations in some of the hydrographic parameters, a square root transformation was applied. If the correlation between pairs of environmental variables was $>0.6$, one of the variables was eliminated. To judge the significance of the relationship between species and environment, a global permutation test was performed. A forward selection CCA was then used to rank environmental variables in their order of importance to determine the pattern of data of the taxa, to test the significance of the variables $(P<0.05)$ and to 


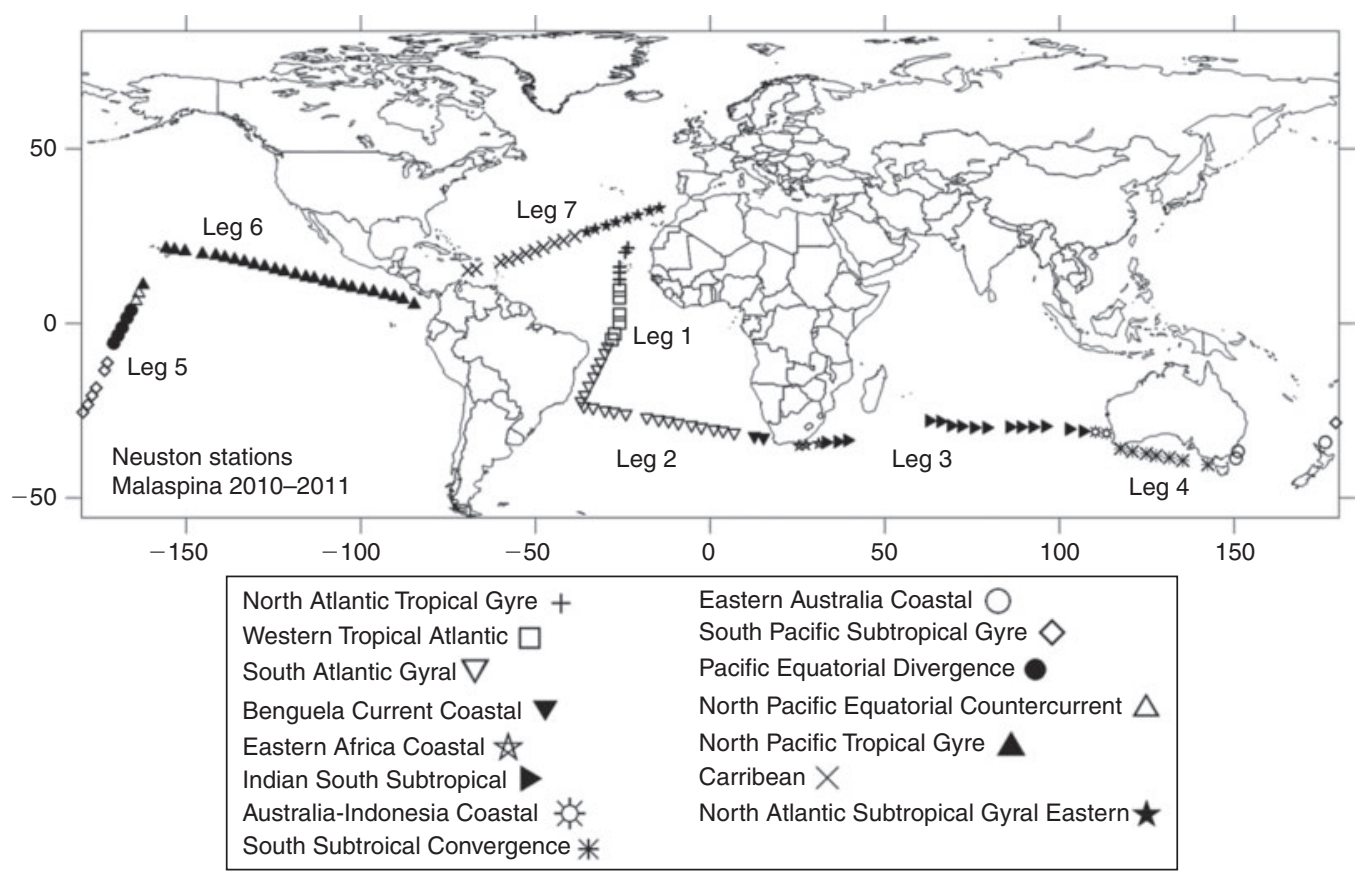

Fig. 1. Neuston stations visited along the Malaspina 2010 circumnavigation expedition. Different symbols are associated to the different Longhurst Provinces (Longhurst 1998).

select only those variables that contributed significantly to explain the variance of species composition.

Estimating the contribution of environmental variables to species distributions might be challenging because these two components tend to be spatially or temporally autocorrelated (Legendre et al. 2005). Thus, the relative contribution of environmental factors and spatial terms (latitude, longitude and up to second order polynomial terms) and seasonality (season of station sampling date, corrected by hemisphere, with stations near to Equator classified as 'equatorial') to neustonic fish assemblages was estimated by variation partitioning analysis to partial out the potential spatial autocorrelation of environmental variables (Legendre and Legendre 2012). The variance of the neustonic composition across stations was partitioned using a partial CCA following the steps detailed in Chust et al. (2013).

For the analysis of adult myctophid assemblages and their linkage with the Longhurst Provinces all myctophid species were included. Due to the absence of myctophids in the daytime samples, only night samples were considered. The PRIMER-6 software package was used (Clarke and Warwick 2005). The groups of samples were defined from the Bray-Curtis similarities coupled with group average linkage. Significant groups of samples were identified using the SIMPROF procedure and using a significance level of $1 \%$. The similarity percentage (SIMPER) routine was then applied to identify the myctophid species with higher contributions to the significant groups of samples.

\section{Results}

\section{Day and night taxonomic composition}

The samples showed clear differences in the abundance and composition of the fish captured in the day and night tows independent of the location of the stations (Table 1). We found at
Table 1. Relative contribution of the different families occurring in neuston samples during night and day samples along the Malaspina expedition

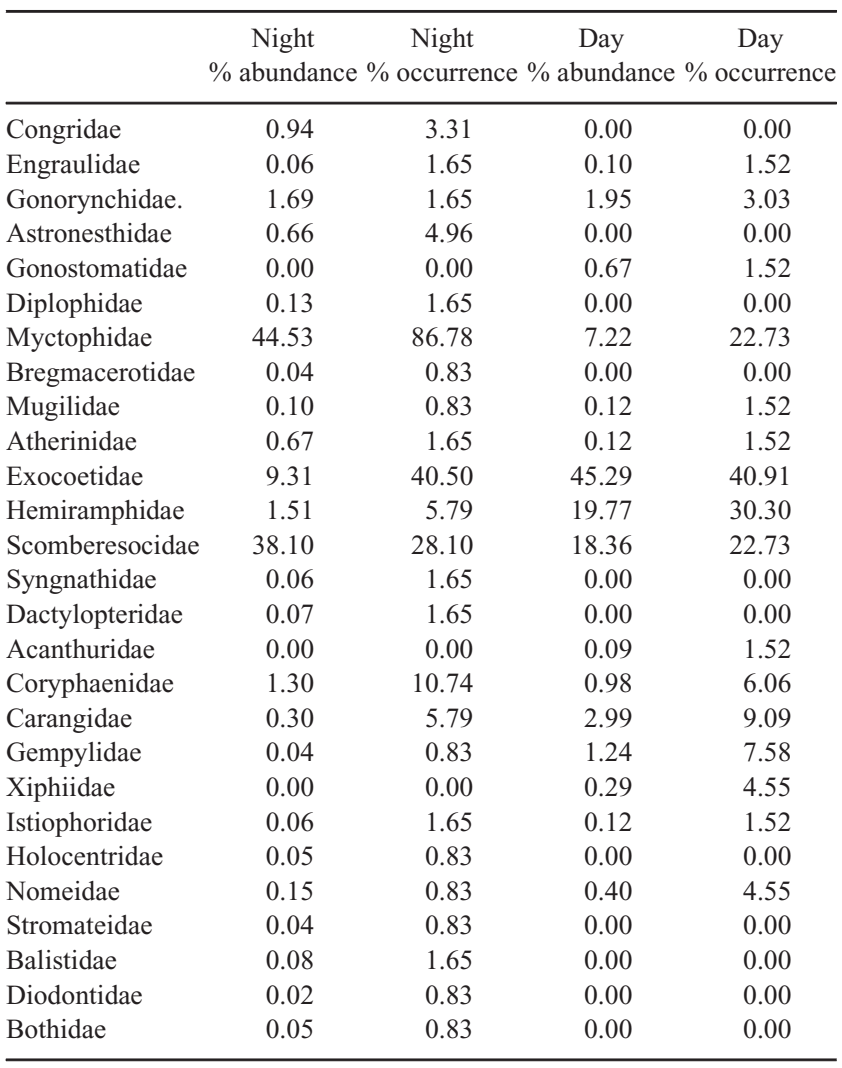


Table 2. Mean abundance (number per $1000 \mathrm{~m}^{2}$ ) of larvae and juveniles collected in day and night neuston samples along the Malaspina expedition Leg location shown in Fig. 1

\begin{tabular}{|c|c|c|c|c|c|c|c|c|c|c|c|c|c|c|c|}
\hline \multirow{2}{*}{$\begin{array}{l}\text { Leg } \\
\text { Family }\end{array}$} & \multirow[b]{2}{*}{ Species } & \multicolumn{2}{|c|}{1} & \multicolumn{2}{|c|}{2} & \multicolumn{2}{|c|}{3} & \multicolumn{2}{|c|}{4} & \multicolumn{2}{|c|}{5} & \multicolumn{2}{|c|}{6} & \multicolumn{2}{|c|}{7} \\
\hline & & Mean & s.d. & Mean & s.d. & Mean & s.d. & Mean & s.d. & Mean & s.d. & Mean & s.d. & Mean & s.d. \\
\hline Congridae & Ariosoma balearicum & & & & & & & & & & & & & 1.37 & 4.24 \\
\hline Engraulidae & Engraulis spp. & & & 0.03 & 0.15 & 0.03 & 0.18 & & & 0.05 & 0.23 & & & & \\
\hline Gonorynchidae & Gonorynchus spp. & & & & & 0.03 & 0.16 & 5.41 & 14.64 & & & & & & \\
\hline Astronesthidae & Astronesthes spp. & 0.09 & 0.36 & & & & & & & & & & & 0.63 & 1.66 \\
\hline Gonostomatidae & Cyclothone spp. & & & & & & & & & & & 0.15 & 0.98 & & \\
\hline Diplophidae & Diplophos maderensis & 0.11 & 0.60 & & & & & & & 0.05 & 0.21 & & & & \\
\hline Myctophidae & Bolinichthys spp. & 1.16 & 5.03 & 0.33 & 1.61 & 0.33 & 1.29 & & & & & 0.02 & 0.15 & & \\
\hline Myctophidae & Ceratoscopelus warmingii & & & 0.19 & 0.92 & & & & & & & & & & \\
\hline Myctophidae & Lampadena luminosa & 0.14 & 0.56 & 0.60 & 2.76 & 9.79 & 53.11 & & & & & & & & \\
\hline Myctophidae & Lampanyctus sp. & & & 0.19 & 0.92 & & & & & & & & & & \\
\hline Myctophidae & Lepidophanes gaussi & & & 0.14 & 0.69 & 0.03 & 0.19 & & & & & & & & \\
\hline Myctophidae & Taaningichthys spp. & & & & & 0.26 & 0.98 & & & & & 0.42 & 1.99 & & \\
\hline Bregmacerotidae & Bregmacerotidae & & & & & & & & & & & 0.03 & 0.19 & & \\
\hline Mugilidae & Mugilidae & 0.04 & 0.21 & 0.13 & 0.62 & & & & & & & & & & \\
\hline Atheriniforme & Atheriniforme & 0.69 & 3.72 & 0.03 & 0.15 & & & & & & & & & 0.04 & 0.21 \\
\hline Exocoetidae & Exocoetidae & 12.90 & 39.68 & 3.59 & 5.51 & 1.90 & 2.64 & 0.37 & 1.34 & 0.19 & 0.38 & 4.04 & 9.88 & 0.89 & 1.52 \\
\hline Hemiramphidae & Hemiramphidae & 1.16 & 2.58 & 0.32 & 1.38 & & & & & 0.46 & 1.35 & 4.02 & 9.22 & 0.44 & 1.29 \\
\hline Scomberesocidae & Cololabis saira & & & & & & & & & & & 18.75 & 54.53 & & \\
\hline Scomberesocidae & Scomberesox saurus & & & 8.27 & 22.82 & 0.17 & 0.91 & 11.35 & 16.15 & 0.43 & 1.87 & & & 6.19 & 13.32 \\
\hline Syngnathidae & Syngnathidae & 0.04 & 0.22 & 0.03 & 0.17 & & & & & & & & & & \\
\hline Dactylopteridae & Dactylopterus volitans & 0.04 & 0.22 & 0.05 & 0.23 & & & & & & & & & & \\
\hline Acanthuridae & Acanthurus spp. & & & 0.04 & 0.18 & & & & & & & & & & \\
\hline Coryphaenidae & Coryphaena equiselis & 0.91 & 3.33 & 0.20 & 0.57 & 0.17 & 0.45 & & & & & 0.21 & 0.89 & 0.11 & 0.56 \\
\hline Coryphaenidae & Coryphaena hypurus & & & & & 0.03 & 0.18 & & & & & & & & \\
\hline Carangidae & Carangidae & & & & & & & 0.09 & 0.31 & & & & & & \\
\hline Carangidae & Naucrates ductor & & & & & 0.04 & 0.20 & 0.32 & 0.89 & 0.05 & 0.20 & 0.68 & 1.98 & 0.04 & 0.22 \\
\hline Gempylidae & Gempylidae & 0.38 & 0.93 & & & & & & & & & & & 0.08 & 0.40 \\
\hline Xiphidae & Xiphias gladius & 0.03 & 0.18 & 0.03 & 0.17 & & & & & & & & & 0.04 & 0.20 \\
\hline Istiophoridae & Istiophoridae & 0.07 & 0.25 & & & 0.04 & 0.22 & & & & & & & & \\
\hline Holocentridae & Holocentridae & & & & & & & & & & & & & 0.06 & 0.31 \\
\hline Nomeidae & Nomeus gronovii & 0.16 & 0.87 & & & 0.08 & 0.31 & & & & & & & & \\
\hline Nomeidae & Psenes maculatus & & & & & & & & & & & & & 0.05 & 0.27 \\
\hline Stromateidae & Peprilus sp. & & & & & 0.04 & 0.24 & & & & & & & & \\
\hline Balistidae & Balistidae & & & & & & & & & & & & & 0.09 & 0.32 \\
\hline Diodontidae & Diodon & 0.03 & 0.14 & & & & & & & & & & & & \\
\hline Bothidae & Bothidae & 0.06 & 0.31 & & & & & & & & & & & & \\
\hline
\end{tabular}

least 26 species (16 families) in day samples and at least 53 species ( 25 families) at night. The day samples were dominated by larvae and juvenile stages of Beloniformes $(45 \%$ of Exocoetidae, $20 \%$ of Hemiramphidae and $18 \%$ of Scomberesocidae). Other frequent species, although never highly abundant, belonged to the families Carangidae, Gempylidae or Coryphaenidae and were represented by late larval and early juvenile stages. At night, adult and juvenile myctophids dominated in both number (45\%) and frequency of occurrence (42\%). The prevailing neustonic families Scomberesocidae and Exocoetidae represented 38 and $9 \%$ of the overall night abundance. The rest of the taxa were represented in the night samples by a high number of species but with a low abundance and low frequency of occurrence (Table 1). Mesopelagic fishes showed a conspicuous difference in ontogenetic stages between day and night. The day samples consisted only of larval stages of the families Gonostomatidae and Myctophidae, whereas the night samples were widely dominated by juvenile and adult Myctophidae and a few juvenile Astronestidae.

\section{Families' distribution patterns}

According to the open sea location of stations, most of the samples' composition consisted of oceanic species. Note that there are some species with very low abundance $(<0.05$ number per $1000 \mathrm{~m}^{2}$ ) that typically correspond to those found in only one of the stations (Tables 2,3). A noteworthy result was the collection of postflexion larvae of several neritic species far from their home regions. This was the case for an engraulid, the anchovy Engraulis encrasicolus, and for the gonorynchid Gonorynchus gonorynchus, both found near the southern tip of Africa, and for E. australis and G. greyi, captured to the west of New Zealand and off south-eastern Australia respectively. Leptocephali of Ariosoma balearicum (Congridae) were found at one station of the Caribbean Province and at three stations of 
Table 3. Mean abundance (number $/ 1000 \mathrm{~m}^{2}$ ) of adult myctophids collected in night neuston samples along the Malaspina expedition Leg location shown in Fig. 1

\begin{tabular}{|c|c|c|c|c|c|c|c|c|c|c|c|c|c|c|}
\hline \multirow{2}{*}{$\begin{array}{l}\text { Leg } \\
\text { Species }\end{array}$} & \multicolumn{2}{|c|}{1} & \multicolumn{2}{|c|}{2} & \multicolumn{2}{|c|}{3} & \multicolumn{2}{|c|}{4} & \multicolumn{2}{|c|}{5} & \multicolumn{2}{|c|}{6} & \multicolumn{2}{|c|}{7} \\
\hline & Mean & s.d. & Mean & s.d. & Mean & s.d. & Mean & s.d. & Mean & s.d. & Mean & s.d. & Mean & s.d. \\
\hline Centrobranchus andreae & & & & & & & & & & & 0.09 & 0.46 & & \\
\hline Centrobranchus coerocephalus & & & & & & & & & 0.30 & 0.65 & 0.17 & 0.82 & & \\
\hline Centrobranchus nigroocelatus & 1.50 & 2.39 & 0.49 & 1.33 & 2.03 & 3.43 & 0.75 & 1.75 & & & & & 1.63 & 2.56 \\
\hline Gonichthys cocco & 0.27 & 0.64 & 1.14 & 1.91 & & & & & & & & & 7.99 & 18.62 \\
\hline Gonichthys barnesi & & & 1.18 & 2.71 & 0.85 & 1.77 & 1.64 & 4.51 & & & & & & \\
\hline Gonichthys venetus & & & & & & & & & 0.18 & 0.50 & & & & \\
\hline Hygophum hanseni & & & & & & & 0.36 & 1.08 & & & & & & \\
\hline Hygophum hygomii & & & & & & & 0.46 & 1.39 & & & & & & \\
\hline Hygophum proximum & & & & & & & & & & & 0.04 & 0.20 & & \\
\hline Hygohum reinhardti & & & 0.03 & 0.12 & & & & & & & & & & \\
\hline Loweina rara & 0.09 & 0.37 & & & & & & & & & & & & \\
\hline Myctophum affine & 2.11 & 8.67 & & & & & & & & & & & & \\
\hline Myctophum asperum & 7.13 & 15.11 & & & 0.83 & 3.23 & 3.83 & 7.79 & 1.98 & 2.95 & 0.13 & 0.62 & 0.71 & 2.42 \\
\hline Myctophum nitidulum & 2.00 & 3.86 & 0.60 & 1.73 & 0.49 & 0.92 & 1.84 & 4.20 & 1.83 & 3.79 & 0.13 & 0.47 & 2.13 & 4.33 \\
\hline Myctophum obtusiroste & 0.54 & 2.30 & & & & & & & & & & & & \\
\hline Myctophum phengodes & & & 0.31 & 0.88 & 0.45 & 1.11 & 0.32 & 0.64 & & & & & & \\
\hline Myctophum punctatum & & & & & & & & & & & & & 0.06 & 0.28 \\
\hline Myctophum spinosum & & & & & & & & & 7.15 & 11.93 & 0.86 & 2.85 & & \\
\hline Symbolophorus evermanni & & & & & 0.18 & 0.59 & & & 0.71 & 1.45 & 0.16 & 0.78 & & \\
\hline Symbolophorus veranyi & & & & & & & & & & & & & 0.06 & 0.26 \\
\hline
\end{tabular}

the North Atlantic Tropical Gyre Province. Conversely, a broad distribution was found for juveniles of the coryphaenid Coryphaena equiselis and the carangid Naucrates ductor, which appeared in each of the three oceans (Fig. 2).

Among the neustonic dwelling species, the most notable result was the finding that the distributions of the scomberesocid Scomberesox saurus and Cololabis saira showed higher concentrations near the large anticyclonic oceanic gyres, whereas Exocoetidae appeared at almost all the stations across the three oceans (Fig. 2 and Table 2).

When environmental variables with pairwise correlations higher than 0.6 were excluded from the ordination analysis the original matrix was reduced to SST, Max. F, Min. $\mathrm{O}_{2}$, T400 and light. The CCA using the abundance of 13 families showed that three selected environmental variables explained $10.5 \%$ of the variance, $6.9 \%$ was explained by spatial autocorrelation, $2.7 \%$ by season and $2 \%$ by the combined effect of environmental variables, season and spatial terms. The relationship between the species and the environmental variables was highly significant $(P<0.002, F=13.213$ for the first canonical axes and $P<0.002, F=5.913$ for all canonical axes). Forward selection of the most important environmental variables showed significant effects of SST, Light and Min. $\mathrm{O}_{2}$ (Table 4). The highest correlations between axes and environmental variables were for SST, negatively correlated with the first canonical axis $(-0.7282)$, and light, with a positive correlation with the second axis (0.6499) and negatively correlated with Min. $\mathrm{O}_{2}(-0.2014)$. The spatial distributions of the scores on Axis 1 and those of SST were in close agreement (Fig. 3). Likewise, the triplot of families, environmental variables and stations (Fig. 4) separated the mesopelagic families Myctophidae and Astronestidae (mostly composed by juvenile and early adult stages), associated with night samples, from Scombridae, Carangidae, Hemiramphidae and Gempylidae (mostly late larvae and juvenile stages), associated with daylight. Environmental variables at deeper layers were only related to the families Myctophidae, Astronestidae and Congridae. The typical tropical and subtropical families were grouped on the negative side of Axis 1, associated with the highest SST. In contrast, Gonorynchidae and Scomberesocidae were associated with the lowest SST. Fluorescence showed a slight relationship with flying fishes and no relationship with mesopelagic families.

\section{Myctophid distribution patterns}

Most of the families were represented by a few species ( 1 or 2 species per family and $\sim 10$ for Exocoetidae), but Myctophidae were the most diverse family in this study, up to 28 species were identified (Tables 2, 3). The main genera were Myctophum (8 species), Gonichthys (4 species), Centrobranchus (3 species), Symbolophorus (2 species) and a few specimens of the genus Hygophum (4 species). The sizes of the individuals collected ranged from $\sim 20$ to $110 \mathrm{~mm}$, with the majority of individuals between 25 and $35 \mathrm{~mm}$, which indicated that they were immature and mature fishes. Furthermore, other myctophids were represented by postflexion larval stages, i.e. Bolinychthys sp., Ceratoscopelus warmingii, Lampadena luminosa, Lampanystus spp., Lepidophanes gaussi and Taaningichthys spp.; however, their adult stages were not recorded in the neuston (Tables 2, 3).

The most abundant myctophids in the neuston night samples were M. asperum and Gonichthys cocco (which reached up to $\sim 50-80$, individuals per $1000 \mathrm{~m}^{2}$ ) (Table 2). Several species, 

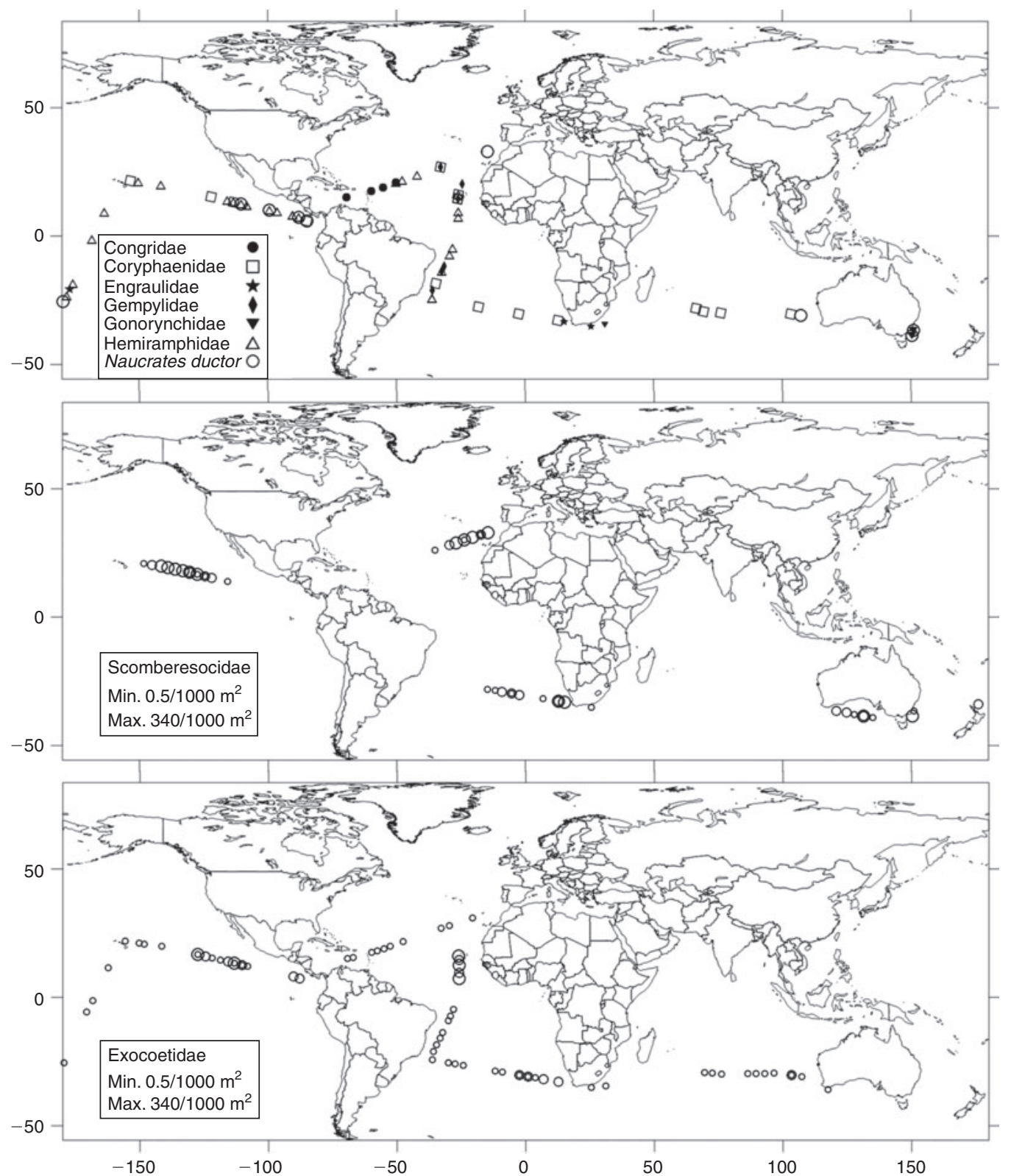

Fig. 2. Spatial distribution of the most frequent families occurring in day and night neuston samples along the Malaspina 2010 circumnavigation expedition.

such as C. nigroocellatus, M. nitidulum and M. asperum, showed a broad distribution in the three oceans, although others appeared exclusively in the southern hemisphere, e.g. M. phengodes and G. barnesi (South Atlantic and South Indian respectively). More restricted distributions were observed for $M$. affine, in the Equatorial Atlantic, M. spinosum in the Equatorial Pacific, and M. aurolaternatum and G. tenuiculus in the Equatorial North Pacific (Fig. 5, Table 3).

The CCA for the most common and abundant 13 myctophid species showed that the four environmental variables (SST, Max. F, Min. $\mathrm{O}_{2}, \mathrm{~T} 400$ ) explained $10 \%$ of the variance of species composition, partialling out the effect of spatial autocorrelation and season (Fig. 6). The partitioning procedure showed that spatial terms explained $17 \%$ of the variance and that $13 \%$ of the variance corresponded to a shared component explained by spatial terms, environment and season. The contribution of season (without taking into account the shared component) is negligible $(0.7 \%)$. The relationship between species and environmental variables was highly significant. Among the environmental variables, the strongest contributor to this relationship was Min. $\mathrm{O}_{2}$, followed by Max. F, SST, and, to a lesser extent, T400 (all statistically significant) (Table 5). The strongest correlations between axes and environmental variables were the negative correlation between Axis 1 and Min. $\mathrm{O}_{2}(-0.7891)$ and the negative correlation between Axis 2 and SST (-0.3544) (Table 5). The spatial distribution of 
positive and negative scores on Axis 1 agreed with that of Min. $\mathrm{O}_{2}$ (Fig. 7). The triplot of myctophid species, environmental variables and stations (Fig. 8) clearly contrasted G. tenuiculus and $M$. aurolaternatum with the other myctophids. G. tenuiculus and $M$. aurolaternatum were positively correlated with Axis 1 and associated with the lowest Min. $\mathrm{O}_{2}$ and the highest Max. F values. Axis 2 showed the opposite ordination. Species such as G. cocco, G. barnesi and M. phengodes, associated with lower SST and higher T400, were separated on Axis 2 from others such

Table 4. Canonical correspondence analysis for $\mathbf{1 3}$ families and five environmental variables

Individual environmental variables in order according to the proportion of variance explained (Exp. Var.); the significance of each variable $(P)$ together with its test statistic ( $F$-value); and inter-set correlations of environmental variables with the first two axes

\begin{tabular}{|c|c|c|c|c|c|}
\hline \multicolumn{6}{|l|}{ Families } \\
\hline \multirow[b]{2}{*}{ Variable } & \multicolumn{3}{|c|}{ Conditional effects } & \multicolumn{2}{|c|}{ Interset correlations } \\
\hline & Exp. Var. (\%) & $P$ & $F$ & $\mathrm{~A} \times \mathrm{e} 1$ & $\mathrm{~A} \times \mathrm{e} 2$ \\
\hline SST & 7.04 & 0.001 & 13.17 & -0.7282 & -0.1436 \\
\hline Light & 5.41 & 0.001 & 10.67 & -0.2936 & 0.6499 \\
\hline Min. $\mathrm{O}_{2}$ & 1.37 & 0.003 & 2.74 & 0.3299 & -0.2014 \\
\hline T400 & 0.64 & 0.248 & 1.27 & -0.1122 & -0.2719 \\
\hline Max. F & 0.33 & 0.615 & 0.64 & -0.1645 & 0.1642 \\
\hline
\end{tabular}

as $M$. spinosum, $C$. choerocephalus and $S$. evermannii, which were associated with higher SST.

The similarity analysis of stations was based on the composition and abundance of all adult myctophid species caught

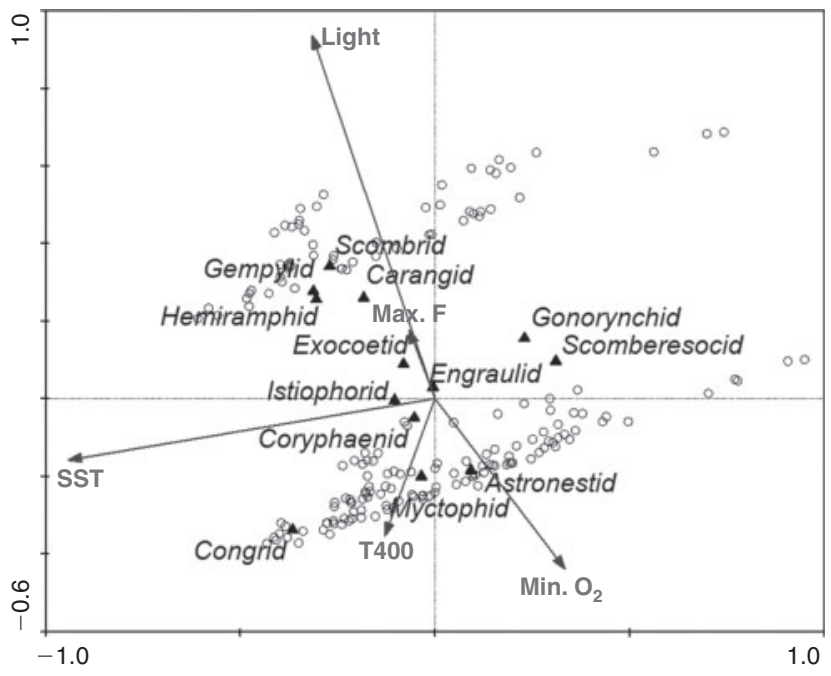

Fig. 4. Plots of axes 1 and 2 derived from a canonical correspondence analysis (CCA) for the 13 most abundant fish families and five environmental variables.

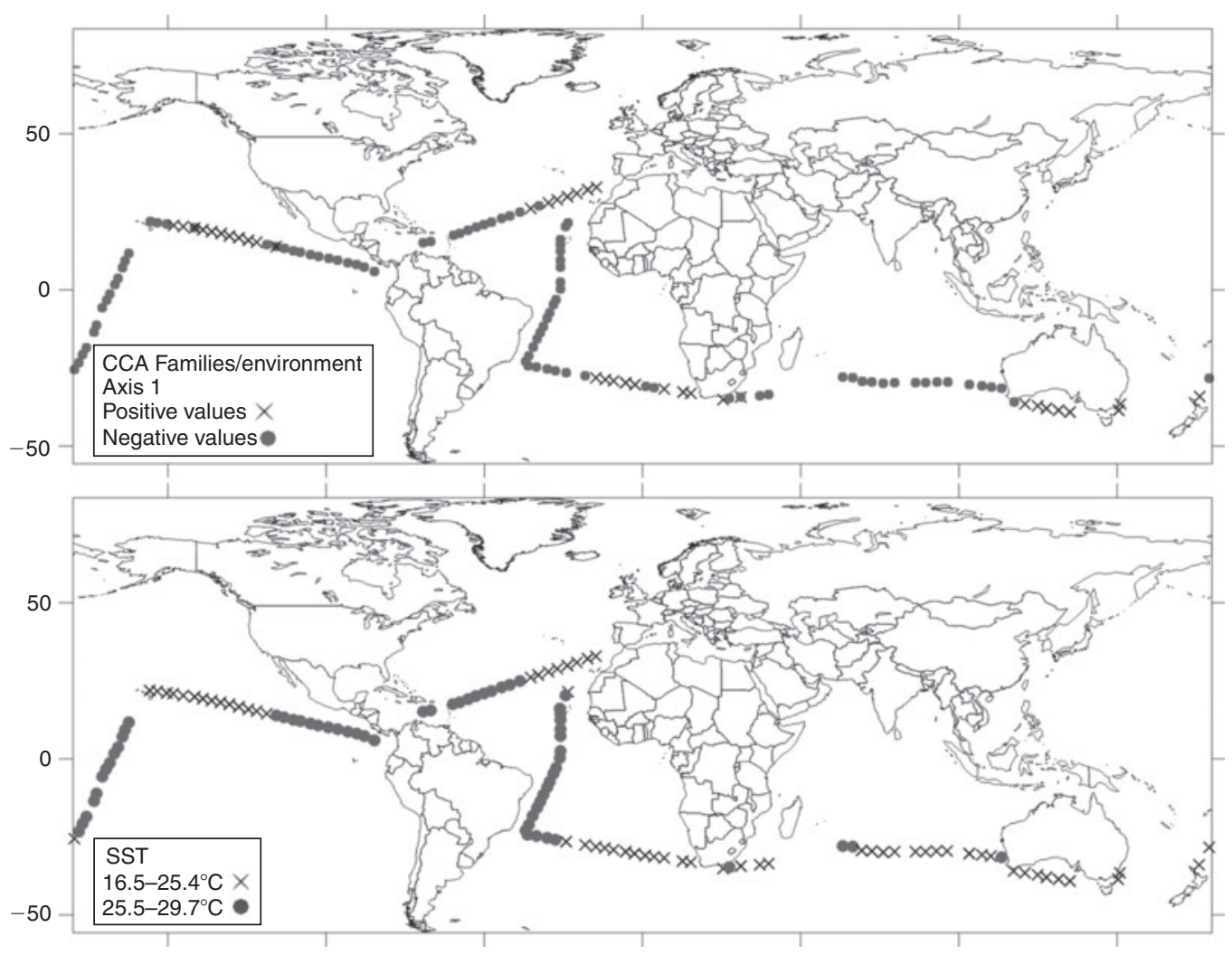

Fig. 3. Sample scores on axis 1 obtained after applying a canonical correspondence analysis (CCA) to family and environmental data (top). Sea surface temperature (SST) per station along the Malaspina 2010 circumnavigation expedition. 

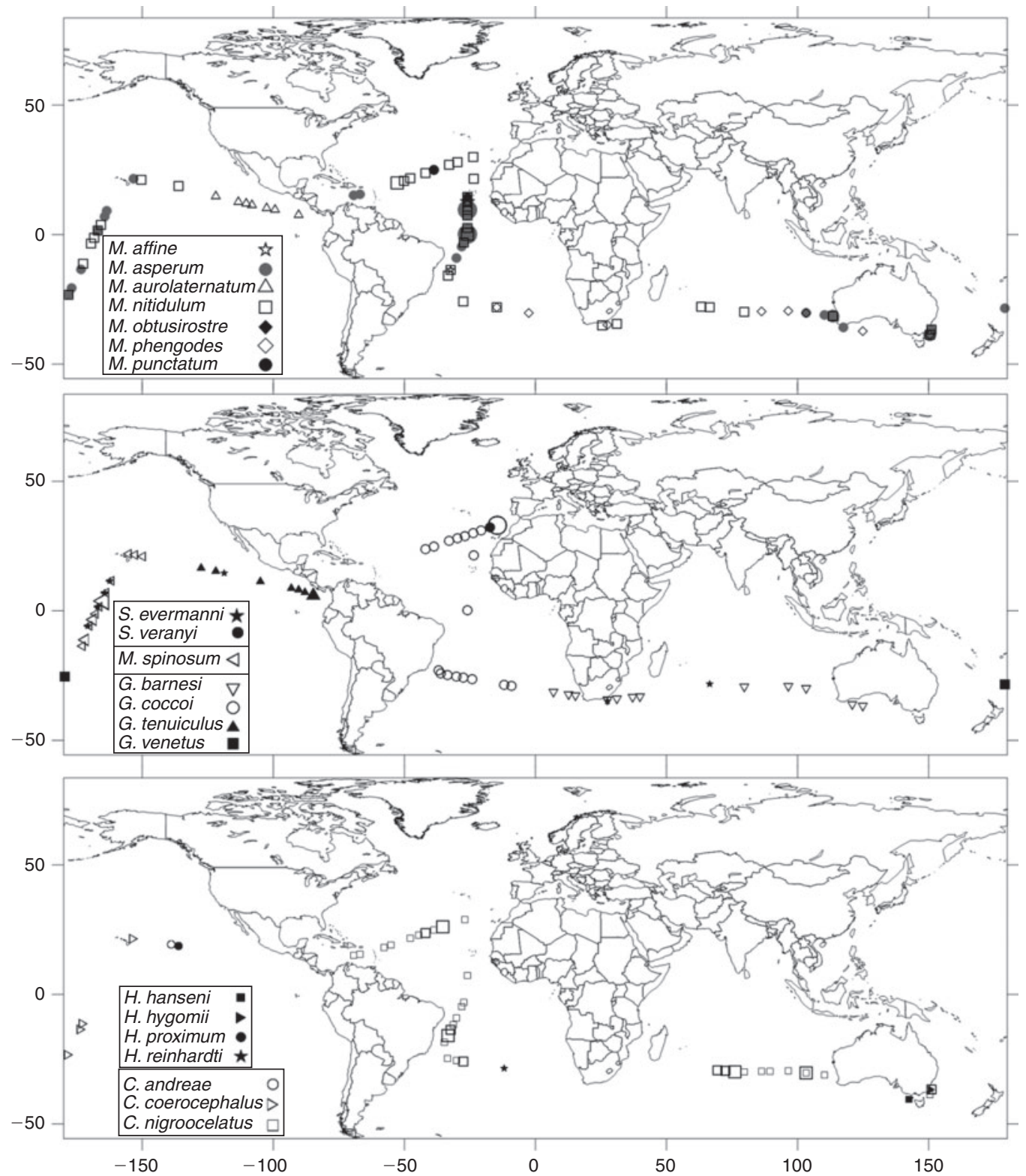

Fig. 5. Spatial distribution of the most frequent species among Myctophidae occurring in night neuston samples along the Malaspina 2010 circumnavigation expedition.

Table 5. Canonical correspondence analysis for 13 species of myctophids and four environmental variables

Individual environmental variables in order according to the proportion of variance explained (Exp. Var.); the significance of each variable $(P)$ together with its test statistic ( $F$-value); and inter-set correlations of environmental variables with the first two axes

\begin{tabular}{lccccc}
\hline \multicolumn{3}{c}{ Myctophid species } & & & \multicolumn{2}{c}{ Interset correlations } \\
& \multicolumn{2}{c}{ Conditional effects } & & \multicolumn{1}{c}{$\mathrm{A} \times 1$} & $\mathrm{~A} \times 2$ \\
Variable & Exp. Var. (\%) & $P$ & $F$ & & \\
\hline Min. $\mathrm{O}_{2}$ & 10.67 & $\mathbf{0 . 0 0 1}$ & 9.5 & -0.7891 & 0.2095 \\
Max. F & 6.03 & $\mathbf{0 . 0 0 1}$ & 5.64 & 0.4479 & 0.4769 \\
$\mathrm{SST}$ & 2.83 & $\mathbf{0 . 0 0 2}$ & 2.75 & 0.5326 & -0.3544 \\
T400 & 2.73 & $\mathbf{0 . 0 0 4}$ & 2.59 & -0.3836 & 0.32 \\
\hline
\end{tabular}

during the expedition, except four species that appeared in only one station and were the only component of the station. Subsequently, the corresponding four stations were not included in the similarity analysis because they were not related to any other one. Under this condition, the analysis revealed seven significant clusters of stations (Fig. 9). A comparison of these groups with the Longhurst Biogeographical Provinces (Fig. 1) showed very few coincidences. Only the first group that included stations located in the North Pacific coincided with the North Pacific Tropical Gyre province. This group was mostly contributed by $G$. tenuiculus $(59.26 \%)$ and $M$. aurolaternatum $(40.74 \%)$. The second group contained stations from the Southern Atlantic and Indian oceans, with major contributions of $G$. barnesi (85.7\%) and M. phengodes (11.99\%). Group three 


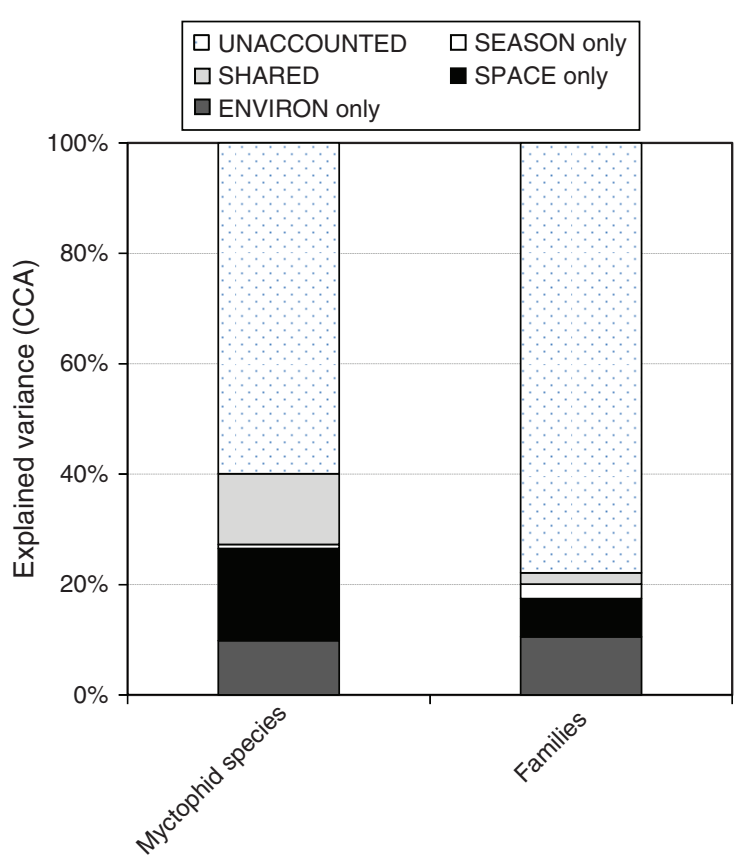

Fig. 6. Variation partitioning (\%) of species composition, based on a canonical correspondence analysis according to spatial terms, season and environmental determinants for each neustonic group.

included stations from the North and South Atlantic and was dominated by G. cocco $(95.57 \%)$. The fourth group was also dominated by a single species $C$. nigroocellatus $(92.69 \%)$ and comprised the stations in the Northern and Southern Atlantic and Southern Indian Oceans. Group five clustered stations from all the oceans and its main composition were due to M. asperum $(84.93 \%)$ and M. nitidulum (12.62\%). All the stations in group six were located in the Pacific (equatorial to Northern Pacific) and were composed by M. spinosum $(88.86 \%)$ and M. nitidulum $(6.75 \%)$, this was the group with highest within group similarity $(56.61 \%)$. Finally, group seven included stations from the three oceans and was constituted just by one species, M. nitidulum $(98.6 \%)$.

\section{Discussion}

The present study was conducted in an extensive area of the world's oceans, allowing comparisons of relative species abundance and composition in the Atlantic, Indian and Pacific Oceans and permitting inferences about their distribution patterns and their relationship with the environmental conditions. First of all, it can be noted that SST distribution (Fig. 3) reflected the difference between tropical and temperate areas. Only a minor displacement towards the south in both limits of the tropical zone could be related to seasonality, as the summer to autumn conditions used to be warmer than winter to spring and early summer. Max. F also showed a seasonal signal since their higher values appeared at stations sampled from mid-spring to early summer (Fig. 7). The taxa accounts showed how the neustonic layers across the three oceans were dominated by the presence of mesopelagic fishes at night, identifying these zooplanktivorous fishes as an important resource competitor for the neustonic dwelling species such as beloniforms or other pelagic species that spent their juvenile stages at this layer, e.g. gempylids (Nakamura and Parin 2001) or scombrids (Habtes et al. 2014).

Late larvae and juveniles of Exocoetidae and adult Myctophidae were found in all the oceans and at most of the stations. Individuals belonging to the Scomberesocidae occurred near the main oceanic gyral zones, indicating a degree of concentration by westerly winds. Both Exocoetidae and Scomberesocidae spend most of their life in surface waters (Collette 2006), but it is likely that the Exocoetidae, with powerful swimming skills, are less susceptible to passive drift and concentration due to surface currents. Although myctophid juveniles and adults appeared in the surface layers exclusively during the night (Roe and Badcock 1984; Gartner et al. 1997; Sassa et al. 2002a, Olivar et al. 2012), the larvae, unable to avoid advective processes, occur during both day and night in the epipelagic layers (Ahlstrom 1959; Sabatés 2004; Sassa et al. 2002b; Olivar et al. 2014), including the neuston, as shown in this study. As a result, the early stages of this oceanic species are more susceptible to drift, which has been related to the large geographic distribution ranges of most myctophids (Hulley 1981).

Observations of higher numbers of species at night are commonly reported for the neuston layers (John 1977; Gartner et al. 1987; Doyle 1992; Doyle et al. 1995) due to the incorporation of vertically migrating species, i.e. juveniles and adults of certain mesopelagic species. Nevertheless, other factors may also contribute to this consistent finding, such as the lower tendency to escape from the net at night or the occurrence of movements to slightly deeper layers at night, as observed in laboratory-reared flying fish larvae (Hunte et al. 1995). SST was identified in this study as an influential environmental variable shaping the distributions of fish families, differentiating scomberesocids and gonorynchids (temperate families) from tropical and subtropical families. Interestingly, Max. F values at the epipelagic layers had a low marginal effect, as this variable was related primarily to true neustonic fishes, whereas only mesopelagic migratory families were related to variables in the deeper layers. A study of the regionalisation of the Southern Ocean based on myctophids has found that to model the distribution of myctophid assemblages, it is necessary to consider not only surface predictors but also deeper ones (Koubbi et al. 2011) as suggested here.

The Myctophidae were the most species-rich fish family taken with the neuston nets, although adults only appeared at night. Not all myctophids reach the neustonic layers in their vertical migrations (Kawaguchi et al. 1972; Gartner et al. 1989, Watanabe et al. 2002), with many species staying below this airwater interface layer. In the present study, we found a conspicuous similarity among the various oceans in the most abundant genera reaching the neuston, with the genera Centrobranchus, Gonichthys and Myctophum found to be the most common along the Malaspina's circumnavigation expedition. Individuals from other genera were also captured by the neuston net, but they were extremely scarce. Note also that other myctophid genera, very abundant and common at night in the near-surface layers (Hulley and Krefft 1985; Gartner et al. 1987; Sutton et al. 2010), were not found in the neuston, e.g. Diaphus, Ceratoscopelus, Lampanyctodes, Lampanyctus, Lampadena, and Lobianchia. Therefore, the data presented here adds new evidence in support 

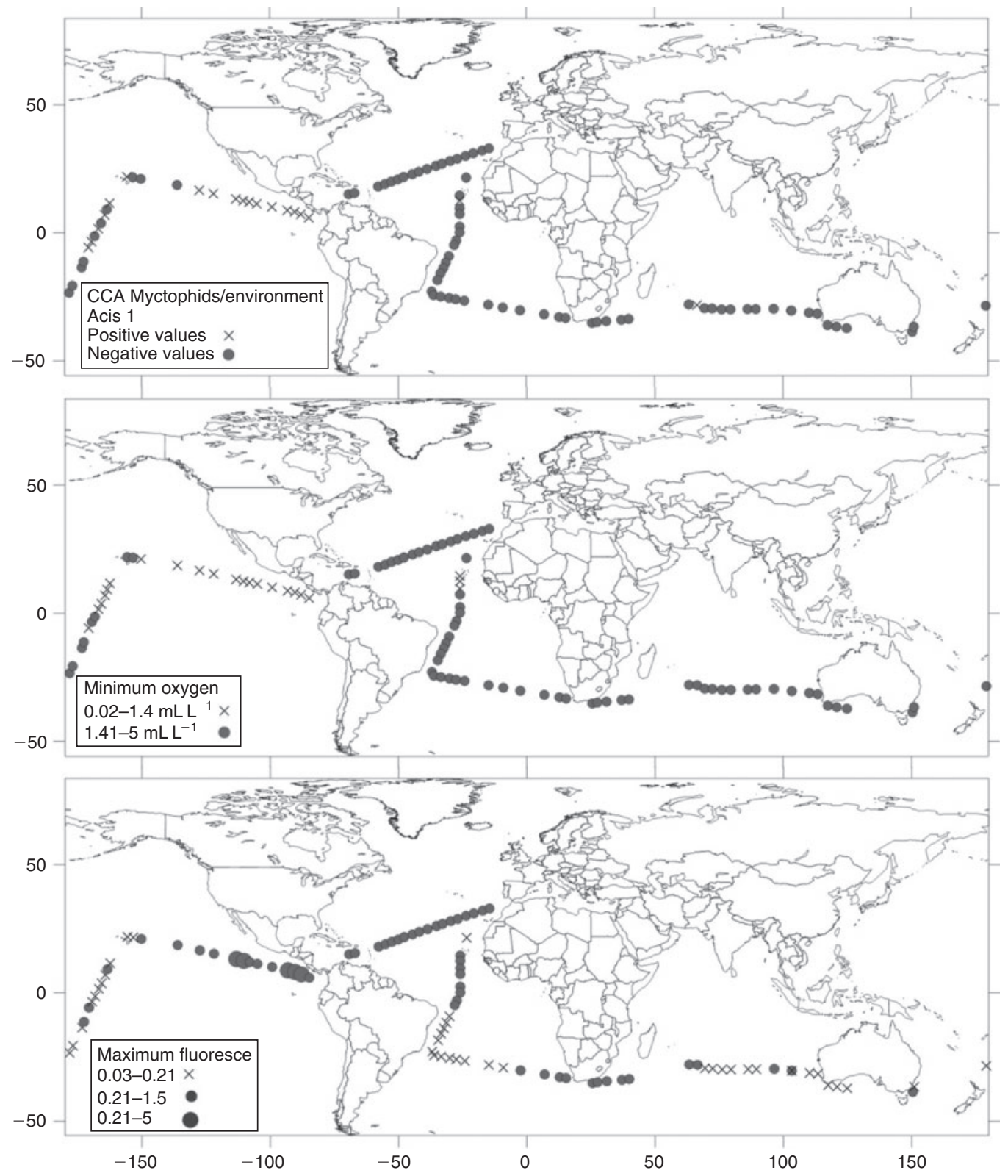

Fig. 7. Sample scores on axis 1 obtained after applying a canonical correspondence analysis (CCA) to 13 species of Myctophidae and environmental data (top). Minimum oxygen $\left(\right.$ Min. $\mathrm{O}_{2}$ ) concentrations per station and maximum fluorescence (Max. F) values in the water column along the Malaspina 2010 circumnavigation expedition.

of the previously indicated pattern of a lack of neustonic migration in genera of the subfamily Lampanyctinae (Paxton 1972; Watanabe et al. 2002).

The biogeographic subdivisions of the world ocean (e.g. van der Spoel and Heyman 1983; Longhurst 1998) show differences in their boundaries, primarily due to differences in the group of species used for the subdivision. The Longhurst Biogeographical Provinces, based on the productivity of the epipelagic zone and seasonal patterns of productivity, were not apparent in our cluster analysis of the myctophid assemblages (i.e. stations belonging to different provinces were included in the same cluster, see Figs 1,9) indicating a widespread distribution of the neustonic migrating myctophids, which could be partly related to their high susceptibility to surface current transport during the periods of staying at the surface.

We are aware that the partial sampling strategy of our study (only the neuston) may not be adequate for a comprehensive biogeographic analysis. However, the distribution patterns observed and their relationship to surface and deep environmental factors are notable and deserve some comments. Myctophid occurrences in relation to temperature patterns have been commonly used to study pelagic zoogeography in particular oceans (Backus et al. 1977, Hulley 1981; Barnett 1984; van der Spoel and Bleeker 1991; Koubbi et al. 2011; Flynn and Marshall 2013). 
All the adult myctophids collected in the survey were high oceanic species belonging to the mesopelagic community, whereas the only representatives of the bathypelagic community were a few larvae of Taaningichthys spp. Our circumnavigation

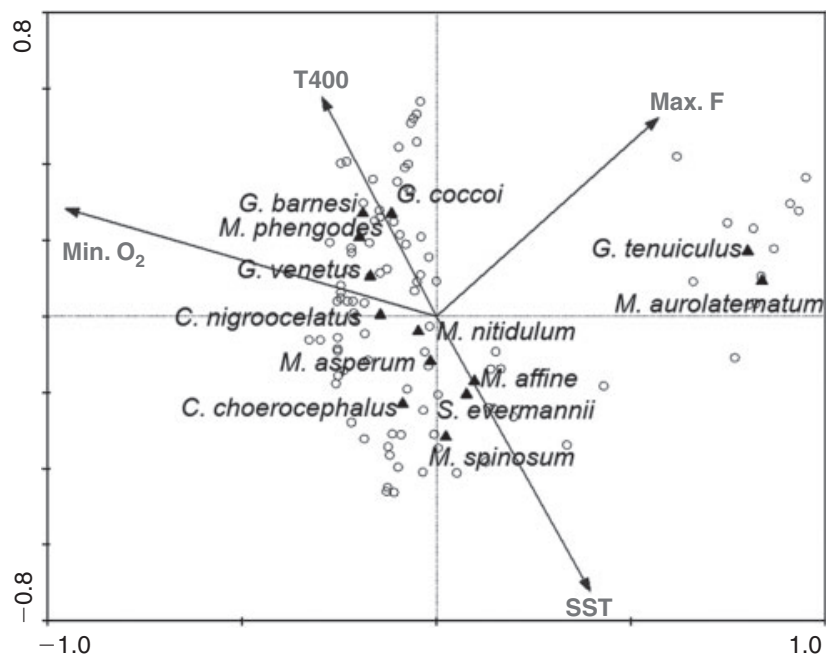

Fig. 8. Plots of axes 1 and 2 derived from a canonical correspondence analysis (CCA) for the 13 species of Myctophidae and four environmental variables. generally crossed tropical and subtropical regions, with just a few samples collected in temperate regions (near the tip of Africa and southern Australia). Accordingly, the most abundant myctophids belonged to the Warm Water Group and fall within Broadly Tropical or Tropical Patterns sensu Hulley (1981). The few occurrences of species of the Cool Water Group were H. hanseni, at a station in the temperate zone near Tasmania, and, $M$. punctatum and $S$. veranyi, also at single stations in the North Atlantic. The most abundant temperate myctophid was G. barnesi appearing in almost all the stations at the subtropical to temperate zones in the southern hemisphere. The south subtropical $M$. phengodes occurred together with G. barnesi, which clustered at the stations of the zoogeographic region encircling the Southern Ocean in the region of the Subtropical Convergence (as in Hulley 1981). G. cocco, which showed a widespread pattern throughout the Atlantic (north and south), was responsible for the similarity among a group of subtropical stations in this ocean. Finally, note that no pseudoceanic species (sensu Hulley 1981) appeared in the neuston samples, even although some of our samples were located not far from regions where some of them are particularly abundant (e.g. Lampanyctodes hectoris in the Benguela region; Hulley 1986a; Flynn and Paxton 2012).

Other environmental variables such as Min. $\mathrm{O}_{2}$ and Max. F showed relation with myctophid distributions in our study. In this regard, we think that the more important effect of Max. F observed when analysing myctophid species in front of the null
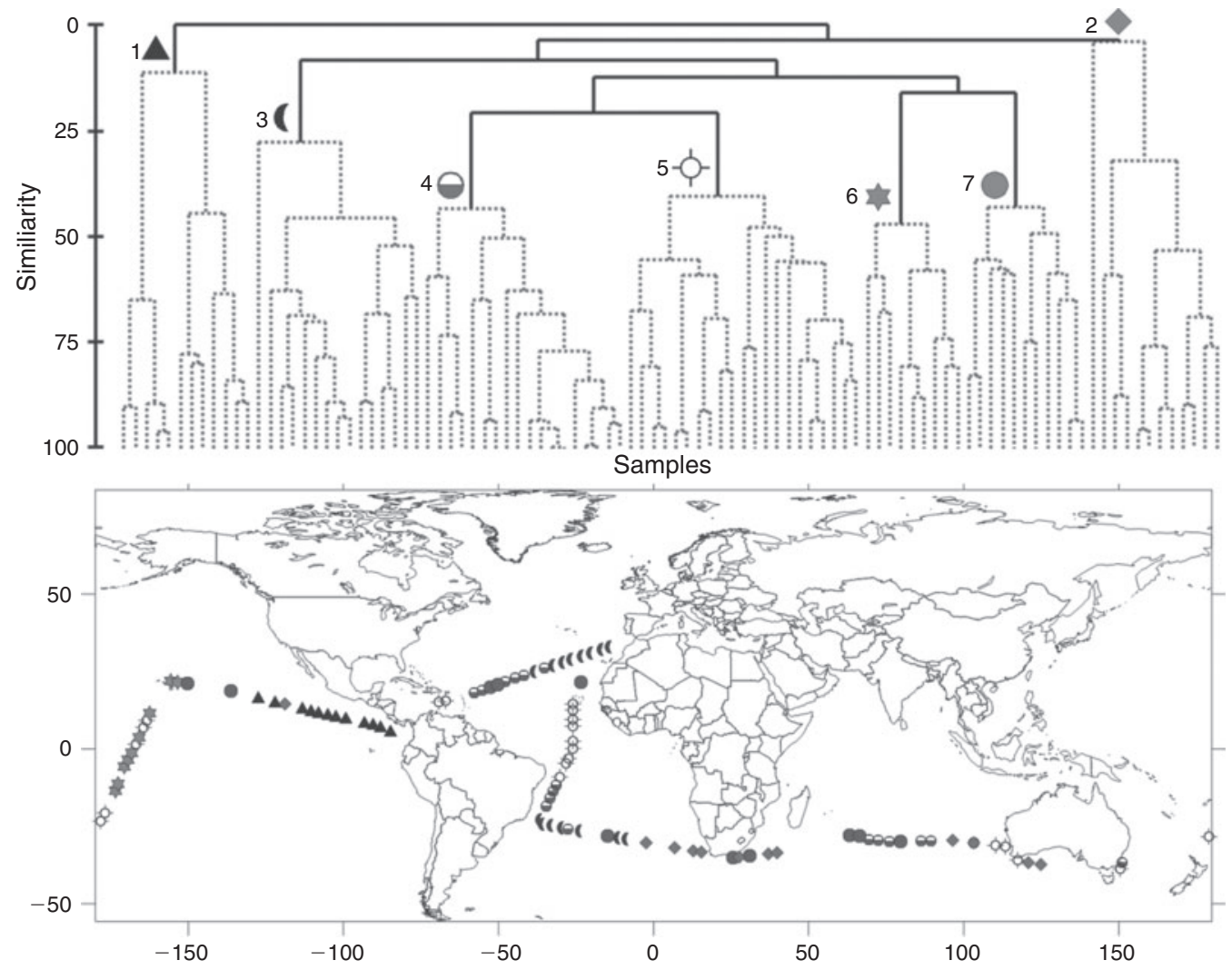

Fig. 9. Dendrogram of similarity among stations obtained after a cluster analysis applied to the Bray-Curtis similarity matrix for myctophid species abundance per sample during the Malaspina 2010 circumnavigation expedition. The seven significant clusters of stations are identified with different symbols whose distribution is shown in the map below. 
influence when working with the entire family, is due to the influence of the stations of the North Pacific Tropical Gyre, with the highest Max. F values of all the survey, which were characterised by the almost exclusive presence of G. tenuiculus and $M$. aurolaternatum. This zone was also affected by the Min. $\mathrm{O}_{2}$ and this could be the reason for the low number of myctophid there. Barnett (1984) noted that the low oxygen concentration in the Eastern Tropical Pacific most likely limits the distribution of mesopelagic species to this area. The importance of $\mathrm{Min} . \mathrm{O}_{2}$ concentrations in the water column has been noted as a relevant issue in mesopelagic fish distributions (Ekau et al. 2010; Koslow et al. 2014), influencing the level of the water column where the adult populations were found during day time (Koslow et al. 2014). It has been suggested that the shallowing of the Min. $\mathrm{O}_{2}$ layer due to climate change may produce a higher predation risk for the mesopelagic fishes which are more vulnerable to visual predators in more illuminated layers (Koslow et al. 2014). Our CCA also denoted how other species such as $M$. spinosum or S. evermanni reflected their higher affinities by tropical warm surface waters, in front of $M$. phengodes, G. cocco and G. barnesi associated with lower SST, which reflected their subtropical or even temperate pattern (for G. barnesi, as in Hulley, 1986b). The species with a broader distribution, M. nitidulum, M. asperum and C. nigroocellatus, were those with less correlation with the environmental variables in CCA because they occurred over a wide range of values.

The variation partitioning analysis showed that environmental factors explained a small but statistically significant portion of the variance of myctophid species and families of neustonic fish assemblages (10 and 11\%). Spatial autocorrelation also explained a non-negligible portion of the taxon assemblages (17\% for myctophid species and $7 \%$ for families), indicating that historical and demographic processes, as well as dispersal constraints, triggering biotic aggregation, also play a role in the distribution pattern of neustonic fish communities. Patterns of mesopelagic fish distributions and diversity have shown geographical covariation with environmental gradients in previous studies, and the maintenance of myctophid zoogeographic regions seem to be the outcome of a mixture of active habitat selection by the adults and passive larval transport (Flynn and Marshall 2013).

In the open ocean, speciation rates across the immense species ranges have been thought to be slow, and these widely distributed pelagic species most likely consist of complexes of genetically different entities that may be either infraspecific or cryptic species (Pierrot-Bults and van der Spoel 2003). The small morphological differences among myctophid species within a genus (these genera have discontinuous distributions in certain instances, e.g. in our study, Gonichthys or some Myctophum species), raise the issue put by Pierrot-Bults and van der Spoel (2003), who questioned whether they are one species or whether several cryptic species are involved. The use of mitochondrial DNA to examine several species of this family has also revealed genetic differences among several species differentiated here based on morphological characters (i.e. M. affine, M. asperum, M. nitidulum, M. orientale and M. punctatum) (Poulsen et al. 2013). However, much more work is needed to understand the speciation mechanisms and the reason for such a large number of species with apparently similar ecological niches.
The present study also notes the high relative abundance of mesopelagic fish in the neuston fish assemblage at night $(>40 \%$ of total fish collected), showing the worldwide daily vertical migrations to the top centimetres of the water column by several myctophid species. The surface ecotone in the open ocean is the destination of buoyant pollutants and resources (e.g. Wurl and Holmes 2008, Cózar et al. 2014), and the concentration of resources in this thin layer should increase the foraging efficiency of the ascending migrants. An intense fish-driven transfer of organic matter from surface to the deep layers of the ocean could have important implications for the biogeochemical and trophic functioning of the open ocean. Mesopelagic fish excrete and defecate into the depths and can also serve as food for larger deep-ocean animals (Longhurst and Harrison 1989). Recently, the biomass of mesopelagic fish in the global ocean was estimated to be 10-fold higher than previously supposed (Koslow et al., 1997; Davison et al. 2013; Irigoien et al. 2014), drawing attention to the influence that vertically migrating mesopelagic fish may have on the overall estimates of carbon fluxes and respiration in the deep ocean.

\section{Acknowledgements}

We are very grateful to all the participants and crew of the Malaspina 2010 expedition for their assistance during the cruise. Mikhail Emelianov was available whenever we needed him to translate the Beeker identification book from Russian. We are really in debt with Dr J. Paxton and Dr A. Williams for allowing the first author to use their drafts of the 'Illustrated Keys to Australian Lanternfishes'. American Journal Experts edited the English version of the manuscript. This study was financed by the Spanish Ministry of Economy and Competitiveness (Consolider-Ingenio 2010, CSD2008-00077 and CTM2012-39587-C04-03).

\section{References}

Ahlstrom, E. H. (1959). Vertical distribution of pelagic fish eggs and larvae off California and Baja California. Fishery Bulletin 161, 107-146.

Angel, M. V. (1997). What is in the deep sea? In 'Deep-Sea Fishes' (Eds D. J. Randall and A. P. Farrell.) pp. 1-41. (Academic Press: London, UK.) Backus, R. H., Craddock, J. E., Haedrich, R. L., and Robison, B. H. (1977). Atlantic mesopelagic zoogeography. Fishes of the Western North Atlantic. Sears Foundation for Marine Research 1, 266-287.

Badcock, J., and Merret, N. R. (1976). Midwater fishes in the eastern North Atlantic. I. Vertical distribution and associated biology in $30^{\circ} \mathrm{N}, 23^{\circ} \mathrm{W}$, with developmental notes on certain myctophids. Progress in Oceanography 7, 3-58. doi:10.1016/0079-6611(76)90003-3

Barnett, M. A. (1984). Mesopelagic fish zoogeography in the central tropical and subtropical Pacific Ocean: species composition and structure at representative locations in three ecosystems. Marine Biology 82(2), 199-208. doi:10.1007/BF00394103

Bekker, V. E. (1983). 'Myctophidae of the World Ocean.' (Academy of Sciences USSR, Institute of Oceanology P.P. Shirshov: Moscow). [In Russian]

Briggs, J. C., and Bowen, B. W. (2012). A realignment of marine biogeographic provinces with particular reference to fish distributions. Journal of Biogeography 39(1), 12-30. doi:10.1111/J.1365-2699.2011.02613.X

Cherel, Y., Verdon, C., and Ridoux, V. (1993). Seasonal importance of oceanic myctophids in king penguin diet at Crozet Islands. Polar Biology 13, 355-357. doi:10.1007/BF00238362

Chust, G., Irigoien, X., Chave, J., and Harris, R. P. (2013). Latitudinal phytoplankton distribution and the neutral theory of biodiversity. Global Ecology and Biogeography 22, 531-543. doi:10.1111/GEB.12016

Clarke, K. R., and Warwick, R. M. (2005). 'Primer-6 Computer Program.' (Natural Environment Research Council: Plymouth, UK.) 
Collette, B. B. (2006). Order Belonifomes. In 'Early Stages of Atlantic Fishes: an Identification Guide for the Western Central North Atlantic'. (Ed W. J. Richards.) p. 903. (Taylor and Francis: Boca Raton, FL, USA.)

Cózar, A., Echevarría, F., González-Gordillo, J. I., Irigoien, X., Ubeda, B., Hernández-León, S., Palma, A. T., Navarro, S., García-de-Lomas, J., Ruiz, A., Fernández-de-Puelles, M. L., and Duarte, C. M. (2014). Plastic debris in the open ocean. Proceedings of the National Academy of Sciences of the United States of America 111, 10239-10244. doi:10.1073/PNAS.1314705111

Davison, P. C., Checkley, D. M., Jr, Koslow, J. A., and Barlow, J. (2013). Carbon export mediated by mesopelagic fishes in the northeast Pacific Ocean. Progress in Oceanography 116, 14-30. doi:10.1016/J.POCEAN. 2013.05 .013

Doyle, M. J. (1992). Neustonic ichthyoplankton in the northern region of the California current ecosystem. California Cooperative Oceanic Fisheries Investigations Reports 33, 141-161.

Doyle, M. J., Rugen, W. C., and Brodeur, R. D. (1995). Neustonic ichthyoplankton in the western Gulf of Alaska during spring. Fishery Bulletin 93, 231-253.

Ekau, W., Auel, H., Portner, H.-O., and Gilbert, D. (2010). Impacts of hypoxia on the structure and processes in pelagic communities (zooplankton, macro-invertebrates and fish). Biogeosciences 7, 1669-1699. doi:10.5194/BG-7-1669-2010

Fahay, M. P. (2007). 'Early Stages of Fishes in the Western North Atlantic Ocean (Davis Strait, Southern Greenland and Flemish Cap to Cape Hatteras).' (Northwest Atlantic Fisheries Organization: Dartmouth, NS, Canada.)

Flynn, A. J., and Marshall, N. J. (2013). Lanternfish (Myctophidae) zoogeography off Eastern Australia: a comparison with physicochemical biogeography. PLoS One 8(12), e80950. doi:10.1371/JOURNAL.PONE. 0080950

Flynn, A. J., and Paxton, J. R. (2012). Spawning aggregation of the lanternfish Diaphus danae (family Myctophidae) in the north-western Coral Sea and associations with tuna aggregations. Marine and Freshwater Research 63, 1255-1271. doi:10.1071/MF12185

Flynn, A. J., and Williams, A. (2012). Lanternfish (Pisces: Myctophidae) biomass distribution and oceanographic-topographic associations at Macquarie Island, Southern Ocean. Marine and Freshwater Research 63, 251-263. doi:10.1071/MF11163

Fock, H. O., and Ehrich, S. (2010). Deep-sea pelagic nekton biomass estimates in the North Atlantic: horizontal and vertical resolution of revised data from 1982 and 1983. Journal of Applied Ichthyology 26(1), 85-101. doi:10.1111/J.1439-0426.2010.01450.X

Gartner, J. V., Hopkins, T. L., Baird, R. C., and Milliken, D. M. (1987). The lanternfishes (Pisces: Myctophidae) of the eastern Gulf of Mexico. Fishery Bulletin 85, 81-98.

Gartner, J. V., Steel, P., and Torres, J. J. (1989). Aspects of the distribution of lanternfishes (Pisces: Myctophidae) from the northern Sargasso Sea Bulletin of Marine Science 45(3), 555-563.

Gartner, J. V., Crabtree, R. E., and Sulak, K. J. (1997). Feeding at depth. In 'Deep-Sea Fishes'. (Eds D. J. Randall and A. P. Farrell.) pp. 115-194. (Academic Press: London, UK.)

Gjøsaeter, J., and Kawaguchi, K. (1980). A review of the world resources of mesopelagic fish. FAO Fisheries Technical Paper 13, 1-151.

Habtes, S., Muller-Karger, F. E., Roffer, M. A., Lamkin, J. T., and Muhling, B. A. (2014). A comparison of sampling methods for larvae of medium and large epipelagic fish species during spring SEAMAP ichthyoplankton surveys in the Gulf of Mexico. Limnology and Oceanography, Methods 12, 86-101. doi:10.4319/LOM.2014.12.86

Hulley, P. A. (1981). Results of the research cruises of FRV Herwig Walther to south-America. 58. Family Myctophidae (Osteichthyes, Myctophiformes). Archiv für Fischereiwissenschaft 31, 1-300.

Hulley, P. A. (1986a). Myctophidae. In 'Smith's Sea Fishes' (Eds M. M. Smith and P. C. Heemstra.) pp. 282-321. (Springer-Verlag: London, UK.)
Hulley, P. A. (1986b). Lanternfishes of the Southern Benguela region. Part 1. Faunal complexity and distribution. Annals of the South African Museum 97(7), 227-249.

Hulley, P. A., and Krefft, G. (1985). A zoogeographic analysis of the fishes of the family Myctophidae (Osteichthyes, Myctophiformes) from the 1979-Sargasso Sea Expedition of R.V. Anton Dohrn. Annals of the South African Museum 96(2), 19-53.

Hunte, W., Oxenford, H. A., and Mahonl, R. (1995). Distribution and relative abundance of flyingfish (Exocoetidae) in the eastern Caribbean Spawning substrata, eggs and larvae. Marine Ecology Progress Series 117, 25-37. doi:10.3354/MEPS117025

Iles, T. D., and Sinclair, M. (1982). Atlantic herring: stock discreteness and abundance. Science 215, 627-633. doi:10.1126/SCIENCE.215. 4533.627

Irigoien, X., Klevjer, T. A., Røstad, A., Martinez, U., Boyra, G., Acuña, J. L., Bode, A., Echevarria, F., Gonzalez-Gordillo, J. I., Hernandez-Leon, S., Agusti, S., Aksnes, D. L., Duarte, C. M., and Kaartvedt, S. (2014). Large mesopelagic fishes biomass and trophic efficiency in the open ocean. Nature Communications 5, 3271. doi:10.1038/NCOMMS4271

John, H.-C. (1977). Die Häufigkeit des Ichthyoplanktons an der Oberfläche des mittleren und südlichen Atlantischen Ozeans. Meeresforsch 25(1-2), 23-36.

Katsuragawa, M., and Matsuura, Y. (1990). Comparison of the diel and spatial distribution patterns of ichthyoplankton and ichthyoneuston in the Southeastern Brazilian Bight. Boletim do Instituto Oceanográfico, Sao Paulo 38(2), 133-146.

Kawaguchi, K., and Aioi, K. (1972). Myctophid fishes of the genus Myctophum (Myctophidae) in the Pacific and Indian Oceans. Journal of the Oceanographical Society of Japan 28, 161-175. doi:10.1007/ BF02108760

Kawaguchi, K., Ikeda, H., Tamura, M., and Ueyanagi, S. (1972). Geographical distribution of surface-migrating myctophid fishes (Genus Myctophum) in the tropical and subtropical Pacific and Indian Oceans. Bulletin of the National Research Institute of Far Seas Fisheries 6, 23-37.

Koslow, J. A., Kloser, R. J., and Williams, A. (1997). Pelagic biomass and community structure over the mid-continental slope off southeastern Australia based upon acoustic and midwater trawl sampling. Marine Ecology Progress Series 146, 21-35. doi:10.3354/MEPS146021

Koslow, A., Davison, P., Lara-Lopez, A., and Ohman, M. D. (2014). Epipelagic and mesopelagic fishes in the southern California Current System: ecological interactions and oceanographic influences on their abundance. Journal of Marine Systems 138, 20-28. doi:10.1016/ J.JMARSYS.2013.09.007

Koubbi, P., Moteki, M., Duhamel, G., Goarant, A., Hulley, P. A., O’Driscoll, R., Ishimaru, T., Pruvost, P., Tavernier, E., and Hosie, G. (2011). Ecoregionalization of myctophid fish in the Indian sector of the Southern Ocean: results from generalized dissimilarity models. Deep-sea Research. Part II, Topical Studies in Oceanography 58, 170-180. doi:10.1016/J.DSR2.2010.09.007

Legendre, P., and Legendre, L. (2012). 'Numerical Ecology', 2nd edn. (Elsevier: Amsterdam.)

Legendre, P., Borcard, D., and Peres-Neto, P. R. (2005). Analyzing beta diversity: partitioning the spatial variation of community composition data. Ecological Monographs 75, 435-450. doi:10.1890/05-0549

Longhurst, H. (1998). 'Ecological Geography of the Sea.' (Academic Press: San Diego.)

Longhurst, A. R., and Harrison, W. G. (1989). The biological pumpprofiles of plankton production and consumption in the upper ocean. Progress in Oceanography 22, 47-123. doi:10.1016/0079-6611(89) 90010-4

Moser, H. G. (Ed.) (1996). 'The Early Stages of Fishes in the California Current Region', Calcofi Atlas number 33. (Allen Press: Lawrence, KS, USA.)

Nakamura, I., and Parin, N. V. (2001). Gempylidae, snake mackerels. In 'The Living Marine Resources of the Western Central Pacific.' 
(Eds. K. E. Carpenter and V. Niem.) FAO species identification guide for fishery purposes. 6. pp. 3698-3708. (FAO: Rome.)

Olivar, M. P., and Fortuño, J. M. (1991). Guide to ichthyoplankton of the Southeast Atlantic (Benguela Current Region). Scientia Marina 55(1), $1-383$.

Olivar, M. P., Bernal, A., Molí, B., Peña, M., Balbín, R., Castellón, A., Miquel, J., and Massutí, E. (2012). Vertical distribution, diversity and assemblages of mesopelagic fishes in the western Mediterranean. Deep-sea Research. Part I, Oceanographic Research Papers 62, 53-69. doi:10.1016/J.DSR.2011.12.014

Olivar, M. P., Sabatés, A., Alemany, F., Balbín, R., Fernández de Puelles, M. L., and Torres, A. P. (2014). Diel-depth distributions of fish larvae off the Balearic Islands (western Mediterranean) under two environmental scenarios. Journal of Marine Systems 138, 127-138. doi:10.1016/J.JMARSYS. 2013.10.009

Paxton, J. R. (1972). Osteology and relationships of the lanternfishes (Family Myctophidae). Bulletin of Los Angeles County Museum of Natural History of Sciences 13, 1-81.

Paxton, J. R., Lavenberg, R. J., and Sommer, C. (1995). Myctophidae, linternillas. In 'Guia FAO para la identificación de especies para los fines de la pesca en el Pacífico centrooriental'. (Eds W. Fischer, F. Krupp, W. Schneider, C. Sommer, K. E. Carpenter and V. Niem.) pp. 1315-1321. (FAO: Rome.)

Pierrot-Bults, A. C., and van der Spoel, S. (2003). Macrozooplankton diversity: how much do we really know? Zoologische Verhandelingen Leiden 345, 297-312.

Poulsen, J., Byrkjedal, I., Willassen, E., Rees, D., Takeshima, H., Satoh, T., Shinohara, G., Nishida, M., and Miya, M. (2013). Mitogenomic sequences and evidence from unique gene rearrangements corroborate evolutionary relationships of myctophiformes (Neoteleostei). BMC Evolutionary Biology 13, 111. doi:10.1186/1471-2148-13-111

Richards, W. J. (2006). 'Early Stages of Atlantic Fishes: an Identification Guide for the Western Central North Atlantic.' (Taylor and Francis: Boca Raton, FL.)

Roe, H. S. J., and Badcock, J. (1984). The diel migrations and distributions within a mesopelagic community in the north-east Atlantic. 5. Vertical migrations and feeding of fish. Progress in Oceanography 13, 389-424. doi:10.1016/0079-6611(84)90014-4

Sabatés, A. (2004). Diel variability of fish larvae distribution during the winter mixing period in the NW Mediterranean. ICES Journal of Marine Science 61, 1243-1252. doi:10.1016/J.ICESJMS.2004.07.022

Sassa, C., Kawaguchi, K., Kinoshita, T., and Watanabe, C. (2002a). Assemblages of vertical migratory mesopelagic fish in the transitional region of the western North Pacific. Fisheries Oceanography 11, 193-204. doi:10.1046/J.1365-2419.2002.00199.X

Sassa, C., Moser, H. G., and Kawaguchi, K. (2002b). Horizontal and vertical distribution patterns of larval myctophid fishes in the Kuroshio current region. Fisheries Oceanography 11, 1-10. doi:10.1046/J.1365-2419. 2002.00182.X

Sinclair, M. (1988). 'Marine Populations.' (University of Washington Press: Seattle, WA, USA.)

Sutton, T. T., Wiebe, R. H., Madin, L., and Bucklin, A. (2010). Diversity and community structure of pelagic fishes to $5000 \mathrm{~m}$ depth in the Sargasso Sea. Deep-sea Research. Part II, Topical Studies in Oceanography 57, 2220-2233. doi:10.1016/J.DSR2.2010.09.024

Ter Braak, C. J. F., and Smilauer, P. (2002). 'CANOCO Reference Manual and CanoDraw for Windows User's Guide: Software for Canonical Community Ordination (version, 4.5).' (Microcomputer Power: Ithaca, NY, USA.)

Tully, O., and ÓCéidigh, P. (1989). The ichthyoneuston of Galway Bay (Ireland). Marine Biology 101(1), 27-41. doi:10.1007/BF00393475

Valls, M., Olivar, M. P., Fernández de Puelles, M. L., Molí, B., Bernal, A., and Sweeting, C. J. (2014). Trophic structure of mesopelagic fishes in the western Mediterranean based on stable isotopes of carbon and nitrogen. Journal of Marine Systems 138, 160-170. doi:10.1016/J.JMARSYS. 2014.04.007

van der Spoel, S. (1994). Response History, progress and future of theory in pelagic biogeography. Progress in Oceanography 34, 101-107. doi:10.1016/0079-6611(94)90003-5

van der Spoel, S., and Bleeker, J. (1991). Distribution of myctophidae pisces myctophiformes during the four seasons in the mid north atlantic. Bijdragen tot de Dierkunde 61(2), 89-106.

van der Spoel, S., and Heyman, R. P. (1983). 'A Comparative Atlas of Zooplankton.' (Springer-Verlag: Berlin, Germany.)

Watanabe, H., Moku, M., Kawaguchi, K., Ishimaru, K., and Ohno, A. (1999). Diel vertical migration of myctophid fishes (Family Myctophidae) in the transitional waters of the western North Pacific. Fisheries Oceanography 8, 115-127. doi:10.1046/J.1365-2419.1999. 00103.X

Watanabe, H., Kawaguchi, K., and Hayashi, A. (2002). Feeding habits of juvenile surface-migratory myctophid fishes (family Myctophidae) in the Kuroshio region of the western North Pacific. Marine Ecology Progress Series 236, 263-272. doi:10.3354/MEPS236263

Wurl, O., and Holmes, M. (2008). The gelatinous nature of the seasurface microlayer. Marine Chemistry 110, 89-97. doi:10.1016/J.MARCHEM. 2008.02.009 